\title{
COVID-19-Related Knowledge, Attitude and Practice Among Hospital and Community Pharmacists in Addis Ababa, Ethiopia
}

This article was published in the following Dove Press journal: Integrated Pharmacy Research and Practice

\author{
Zelalem Tilahun Tesfaye (iD \\ Malede Berihun Yismaw (D) \\ Zenebe Negash \\ Akeberegn Gorems Ayele \\ Department of Pharmacology and \\ Clinical Pharmacy, School of Pharmacy, \\ College of Health Sciences, Addis Ababa \\ University, Addis Ababa, Ethiopia
}

Purpose: This study was launched to assess COVID-19-related knowledge, attitude and practice among hospital and community pharmacists in Addis Ababa, Ethiopia.

Methods: Self-administered questionnaire was distributed to pharmacists working in hospitals and community pharmacies by physically delivering the questionnaire to study subjects. Data collected were entered into and analyzed by IBM SPSS Statistics ${ }^{\circledR}$ Version 25 . Binary logistic analysis was used to determine the association between independent and outcome variables.

Results: All 295 participants who completed the survey stated that they had heard about COVID-19. Almost all of the participants were aware of the causative agent, the clinical manifestations and the ways of transmission of COVID-19. Most participants (92.2\%) identified elderly individuals as one of the high-risk groups for severe complications and death while $89.5 \%$ identified supportive therapy and life support as recommended management options to date. More than half $(53.2 \%)$ of the respondents were found to have adequate knowledge about COVID-19. Among respondents, $89.8 \%$ had a positive attitude on the importance of following WHO recommendations in reducing the transmission of COVID-19. Only $9.8 \%$ had confidence in the capacity of healthcare facilities in the country to properly handle potential COVID-19 pandemic. Inadequate protective measures were taken to protect the staff from COVID-19 in the institutions of $70.2 \%$ of the participants. Among the WHO recommended prevention measures, hand washing was exercised by $97.3 \%$ of the study participants.

Conclusion: The study findings confirmed that there is a high level of knowledge on each specific aspect of COVID-19 among the study participants. However, only about half of the participants had adequate knowledge about the disease. The pharmacists showed a predominantly positive attitude towards the importance of WHO recommendations and predominantly negative attitude towards the country's capacity to deal with the pandemic. The practice related to COVID-19 was inadequate at institutional level. Nevertheless, most of the pharmacists individually exercised self-protective measures against COVID-19. All stakeholders should work on ensuring the adequate supply of materials and services that aid in controlling the pandemic.

Keywords: novel coronavirus, global pandemic, SARS-CoV-2, viral pneumonia, physical distancing

\section{Introduction}

The novel coronavirus $(\mathrm{CoV})$ was initially identified in Wuhan, China, in December 2019 among a group of patients that presented with an unidentified form of viral pneumonia with common history of visiting a seafood market., Later the disease was named Coronavirus Disease-2019 (COVID-19). ${ }^{3}$ Since then,
Correspondence: Zelalem Tilahun Tesfaye Department of Pharmacology and Clinica Pharmacy, School of Pharmacy, College of Health Sciences, Addis Ababa University, Zambia Street, PO Box 9086, Addis

Ababa, Ethiopia

Tel +25I913824722

Email zelalemII@yahoo.com
Integrated Pharmacy Research and Practice 2020:9 105-II2 
the virus has spread all over the world causing an unprecedented number of hospitalizations and fatalities in many countries. On January 30, 2020, the World Health Organization (WHO) declared COVID-19 pandemic as a global public health emergency. ${ }^{4}$

COVID-19 is caused by a virus named Severe Acute Respiratory Syndrome-Coronavirus 2 (SARS-CoV-2), which is a member of $\beta$-CoVs. The $\mathrm{CoV}$ family is a class of enveloped, single-stranded RNA viruses that can cause respiratory, gastrointestinal, hepatic, and neurologic diseases. ${ }^{5}$ The $\mathrm{CoVs}$ are categorized into four subfamilies: $\alpha, \beta, \gamma$, and $\delta$-CoVs. Human CoV infections are caused by $\alpha$ and $\beta$-CoVs. ${ }^{6}$

COVID-19 can cause five different outcomes: asymptomatic infection; mild to moderate cases that often resolve within 2 weeks; severe cases; critical cases; and death. ${ }^{3}$ Data from the first 41 COVID-19 patients show that the initial manifestations of the disease included fever (98\%), cough (76\%), dyspnea (55\%), myalgia (44\%), sputum production $(28 \%)$, headache $(8 \%)$, hemoptysis $(5 \%)$, and diarrhea (3\%). Among these, 29\% developed acute respiratory distress syndrome, $12 \%$ had acute cardiac injury, $7 \%$ had acute kidney injury, and 7\% had shock. ${ }^{7}$

There is no definitive therapy against SARS-CoV-2 yet. Although positive treatment outcomes have been reported with antiviral therapy on selected patients, supportive care and oxygen supplementation remain as the mainstay of the management of COVID-19. ${ }^{89}$ The search for vaccines and therapeutic agents against the virus is underway in many parts of the world. ${ }^{10-14}$ Preventive measures have been forwarded by WHO as major ways of mitigating the outbreak. ${ }^{15}$

Ethiopia reported its first case of COVID-19 on March 13, 2020. ${ }^{16}$ Since then, gradual increment in the number of cases has been reported by the ministry of health. In countries like Ethiopia, where low surveillance and laboratory capacity, scarcity of healthcare human resources, and inadequate financial capacity are defining features of the healthcare system, the outbreak of a cureless viral infection with no vaccine will have a devastating impact. ${ }^{17}$ Due to this, limiting the rate and the extent of COVID-19 outbreak is the best strategy to minimize public health and socioeconomic impact of the pandemic in the country, and healthcare professionals play the central role. ${ }^{18}$

As members of the healthcare workforce, pharmacists bear essential responsibility in overcoming pandemics. In the case of COVID-19, pharmacists' role includes creating public awareness about the disease; manufacturing, distribution, and supply of essential preventive items such as hand sanitizers and personal protective equipment; and participating in research activities aimed at finding vaccines and drugs against the virus. ${ }^{19-21}$

Thus, pharmacists need to have adequate knowledge about COVID-19 in order to successfully exercise their roles in the fight against the disease. To facilitate an urgent response to potential COVID-19 outbreak in Ethiopia, it is important to evaluate the knowledge, attitude and practice of healthcare workers who engage in the response against the outbreak. This study was launched to assess COVID19-related knowledge, attitude and practice among hospital and community pharmacists in Addis Ababa, Ethiopia.

\section{Patients and Methods}

In this cross-sectional survey, a self-administered questionnaire was distributed to pharmacists working in hospitals and community pharmacies in Addis Ababa, Ethiopia. Data were collected during the first 2 weeks since the first COVID-19 case was identified in Ethiopia (from March 16, 2020 to March 30, 2020).

Because there was no complete data available on the number of hospital and community pharmacists working in the city, a sampling frame could not be produced, and hence, subjects were selected by convenience sampling. Hospital pharmacists were enrolled by visiting all (12) public hospitals in the city. All hospital pharmacists who gave consent for participation were included in the study. Privately owned hospitals were not included in the study because, while some have hospital pharmacies as part of the hospital, others have pharmacies that work with community pharmacy licenses and function as both hospital and community pharmacies. Pharmacists from some privately owned hospitals were used to conduct a pilot test on the data collection tool, as these institutions were not included in the main study. To select community pharmacists, we used Google Maps to track community pharmacies in the city. Out of 176 community pharmacies identified in this way, 134 gave us permission to collect data on their premises. All pharmacy professionals who worked at these premises, and gave consent to participate were included in the study. As a result, 350 individuals from hospital and community pharmacies were enrolled in the study.

The data collection instrument was prepared by the investigators. The questionnaire consisted of four sections: socio-demographic characteristics, knowledge, attitude and practice sections. The instrument was checked for face 
validity by independent experts in the field. In addition, a pilot test of 43 samples was used to analyze the internal consistency of the questions in each section of the questionnaire. Sets of questions with Cronbach alpha of 0.6 or more were included in the final version of the questionnaire.

Data were collected by physically delivering the questionnaire to the study participants. After checking for completeness, data collected were entered into IBM SPSS Statistics ${ }^{\circledR}$ Version 25 and subsequently analyzed. Frequency and percentage were used to characterize knowledge, attitude and practice related to COVID-19. In addition, participants' knowledge was characterized as adequate if all of the knowledge questions were correctly answered; and inadequate if one or more knowledge questions were incorrectly answered. Binary logistic analysis was used to identify the potential association between dependent and independent variables, setting p-value $<0.05$ as an indicator of significance. Attitude was assessed using 5-point Likert-type questions. The percentage of positive response (PPR) and average attitude score were calculated. $T$-test and one way ANOVA were used to compare differences in attitude among different groups of respondents. The practice related to COVID-19 was assessed by calculating the frequency and percentage of responses to each practice-related question.

A letter of ethical approval was obtained from the Ethical Review Board of the School of Pharmacy, Addis Ababa University [Ref. No. ERB/SOP/211/04/2020]. Guidelines outlined in the Declaration of Helsinki were met. Written informed consent was provided by all study participants before data collection. Moreover, personal identifiers such as names and addresses of study subjects were not included in the data collected and confidentiality of data was ensured.

\section{Results}

\section{Socio-Demographic and Professional Characteristics}

Out of 350 questionnaires that were distributed, 295 were fully completed and returned, producing a response rate of $84.3 \%$. The majority of respondents $(58.6 \%)$ were aged between 19 and 30 years with a mean age of $32.2 \pm 8.3$ years. About half $(51.5 \%)$ of the respondents were male, nearly two-thirds $(66.4 \%)$ worked in community pharmacies and more than half (54.2\%) had a working experience not more than 5 years (Table 1).
Table I Socio-Demographic and Professional Characteristics

\begin{tabular}{|l|l|}
\hline Variables & Frequency (\%) \\
\hline Age in years & \\
$19-30$ & $173(58.6)$ \\
$31-45$ & $96(32.5)$ \\
$46-62$ & $26(8.8)$ \\
\hline Gender & \\
Female & $143(48.5)$ \\
Male & $152(51.5)$ \\
\hline Professional level & \\
Pharmacy technician & $87(29.5)$ \\
Pharmacist & $208(70.5)$ \\
\hline Job position & \\
Dispenser & $273(92.5)$ \\
Store Manager & $22(7.5)$ \\
\hline Working setup & \\
Community pharmacy & $196(66.4)$ \\
Hospital pharmacy & $99(33.6)$ \\
\hline Year of service & \\
$\leq 5$ & $160(54.2)$ \\
6-15 & $112(38.0)$ \\
$\geq 16$ & $23(7.8)$ \\
\hline
\end{tabular}

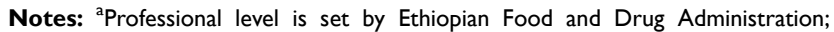
Pharmacy technicians are mid-level professionals with technical and vocational diploma whereas pharmacists are high-level professionals with Bachelor of Pharmacy degree or higher.

\section{Knowledge About COVID-19}

All the participants stated that they had heard about COVID-19. Mainstream media and internet/social media were identified as sources of information by most of the respondents (Figure 1).

Almost all of the participants were aware of the causative agent, the clinical manifestations and the ways of transmission of COVID-19. Most participants (92.2\%) identified elderly individuals as one of the high-risk groups for severe complications and death from COVID-19 while $89.5 \%$ identified supportive therapy and life support as recommended management options to date (Table 2). More than half $(53.2 \%)$ of the study participants were found to have adequate knowledge about COVID-19.

After categorizing knowledge based on knowledge score as adequate (correct answers for all of the knowledge questions) or inadequate (at least one incorrect answer), binary logistic analysis was employed to identify the predictors of the extent of knowledge among respondents. As a result, professional level and service year of participants were found to be predictors of the extent of 


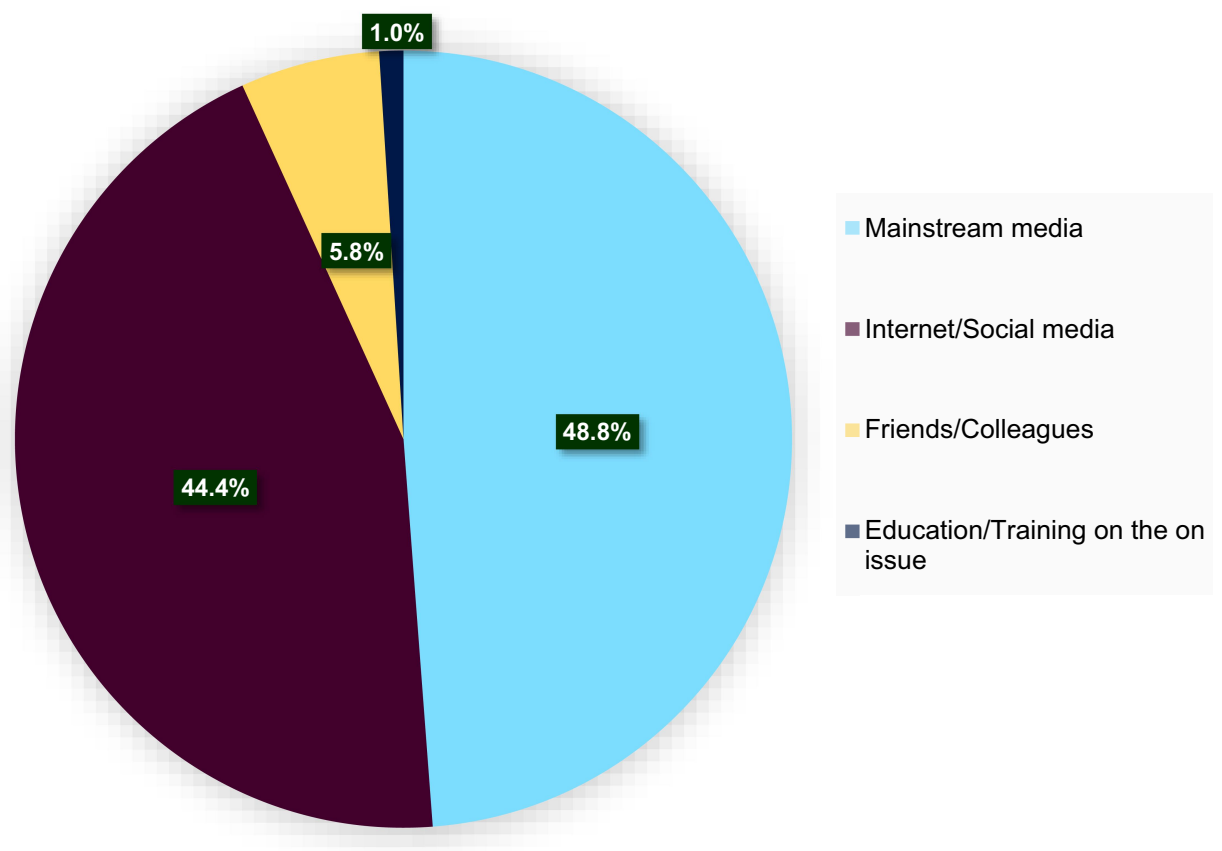

Figure I Sources of information about COVID-19 among hospital and community pharmacists in Addis Ababa, Ethiopia.

knowledge about COVID-19. The odds of having adequate knowledge was higher (AOR: 2.65; CI: 1.50, 4.65) among pharmacists as compared to pharmacy technicians. In addition, participants with six to 15 years of service were more likely to have adequate knowledge about COVID-19 (AOR: 2.12; CI: 1.18, 3.79) as compared to those who served for 5 years or less (Table 3 ).

\section{Attitude Towards COVID-19}

Among the participants, $89.8 \%$ had a positive attitude towards the importance of following WHO recommendations in reducing the transmission of COVID-19 while $81.0 \%$ agreed that they or members of their family could acquire COVID-19 at some time in the future. Regarding healthcare institutions, only $9.8 \%$ had confidence in the capacity of the healthcare facilities in the country to properly handle potential COVID-19 outbreak. The overall percentage of positive response to the attitude questions was $54.1 \%$ (Table 4 ).

$T$-test was performed to identify the difference in attitude scores between different groups of study participants. As a result, there was no significance difference $(p>0.05)$ between female [mean score $=3.59$ ] and male [means score $=3.50$ ] respondents; pharmacy technicians [mean score $=3.58]$ and pharmacists [means score $=3.52$ ]; community pharmacists [mean score $=3.57]$ and hospital pharmacists [mean score $=3.51$ ]; as well as dispensers [mean score $=3.54]$ and store managers [mean score $=$ 3.56]. Similarly, the results of one way ANOVA showed that there was no significant difference ( $p>0.05$ ) across different categories of age group and years of working experience.

\section{Practice Related to COVID-19}

Inadequate protective measures were taken to protect the staff from COVID-19 in the institutions of $70.2 \%$ of participants, and the major reason associated with this was resource scarcity. Moreover, $69.5 \%$ of participants stated that their institution did not provide adequate service related to COVID-19, primarily due to the limited supply of equipment or pharmaceuticals. Among the WHO recommended prevention measures, hand washing was exercised by $97.3 \%$ of the study participants (Table 5).

\section{Discussion}

Ethiopia is one of the thirteen countries considered a top priority by WHO with respect to the need for epidemic response preparedness against COVID-19. ${ }^{22}$ Pharmacists working in hospital and community pharmacies, as members of the healthcare workforce, are integral parts of response against COVID-19 pandemic. $^{19-21}$ This study was initiated to assess COVID-19-related knowledge, 
Table 2 Knowledge About COVID-19 Among Hospital and Community Pharmacists in Addis Ababa, Ethiopia

\begin{tabular}{|c|c|}
\hline Questions and Responses & $\begin{array}{l}\text { Frequency } \\
\text { (\%) }\end{array}$ \\
\hline $\begin{array}{l}\text { What causes COVID-I9? } \\
\text { Virus } \\
\text { Fungus }\end{array}$ & $\begin{array}{l}294(99.7) \\
I(0.3)\end{array}$ \\
\hline $\begin{array}{l}\text { Which organ system does COVID-I } 9 \text { primarily } \\
\text { attack? } \\
\text { Respiratory } \\
\text { Gastrointestinal } \\
\text { Genitourinary } \\
\text { Not sure }\end{array}$ & $\begin{array}{l}29 \mid(98.6) \\
2(0.7) \\
I(0.3) \\
I(0.3)\end{array}$ \\
\hline $\begin{array}{l}\text { What is/are the mode of transmission(s) of } \\
\text { COVID-19? } \\
\text { Through coughing/sneezing into another person } \\
\text { Contact with contaminated surfaces } \\
\text { Direct body contact with infected person } \\
\text { Other }{ }^{\mathrm{b}} \\
\text { Not sure }\end{array}$ & $\begin{array}{l}281(95.3) \\
259(87.8) \\
266(90.2) \\
8(2.7) \\
5(1.7)\end{array}$ \\
\hline $\begin{array}{l}\text { What group of patients are at high risk of } \\
\text { severe disease or death from COVID- } 19 ?^{\mathrm{a}} \\
\text { Children and adolescents } \\
\text { Older adults } \\
\text { People with underlying diseases } \\
\text { Others } \\
\text { Not sure }\end{array}$ & $\begin{array}{l}43(14.6) \\
272(92.2) \\
245(83.1) \\
7(2.4) \\
5(1.7)\end{array}$ \\
\hline $\begin{array}{l}\text { What is WHO recommended management } \\
\text { option for COVID-19? } \\
\text { Traditional medicine } \\
\text { Antimicrobial therapy } \\
\text { Vaccination } \\
\text { Supportive therapy and life support }\end{array}$ & $\begin{array}{l}50(16.9) \\
77(26.1) \\
73(24.7) \\
264(89.5)\end{array}$ \\
\hline
\end{tabular}

Notes: a Multiple responses recorded. ' $O$ ther - airborne (3), eating raw food (2), from animal to human (2), feeding from the same plate (I); ' Others - smokers (4), healthcare workers (2), malnourished (I).

attitude and practice among hospital and community pharmacists in Addis Ababa, the capital of Ethiopia.

In the present study, all the study participants had already heard about COVID-19. The main sources of information identified were mainstream media $(48.8 \%)$ and internet/ social media $(44.4 \%)$. Similarly, government websites, news media, and social media were identified as the main sources of COVID-19-related information among healthcare workers on studies conducted elsewhere. ${ }^{23,24}$ These findings show the importance of the internet and traditional mass media in the transfer of information related to novel coronavirus. However, it is advisable to select information sources carefully to avoid unverified and misleading information.
Almost all of our study participants knew that COVID19 is caused by a virus and it primarily attacks the respiratory system. We also found a high level of knowledge about the way of transmission, risk factors, and management of COVID-19. Fairly lower percentages of correct responses to knowledge questions were recorded in other studies conducted on healthcare workers. ${ }^{23,25}$ The difference could be due to differences in study population, methodology, and time of data collections. As new information about COVID-19 comes out daily, a few weeks' interval between studies can result in a significant difference in knowledge among healthcare workers. Despite a high percentage of correct answers for each knowledge question in our study, only a few more than half of the study participants had adequate knowledge. This implies that the other nearly half were misinformed about one or more aspects of the disease. It is recommended that pharmacists avoid misinformation about COVID-19 because the public relies on information from pharmacists and other healthcare workers to protect themselves from the disease.

Predictors of knowledge about COVID-19 among our study subjects were identified. Accordingly, pharmacists were 2.7 times more likely to have adequate knowledge than pharmacy technicians. Pharmacists hold higher educational and professional status than pharmacy technicians, which may be the reason behind their likelihood to possess adequate knowledge as compared to pharmacy technicians. Similarly, respondents with 6 to 15 years of service were found to be 2.1 times more likely to have adequate knowledge as compared to those who served for 5 years or less. Those with less than 5 years of working experience may not be as effective in choosing the right source of information about COVID-19 as their senior colleagues, hence affecting their knowledge about the disease.

Regarding attitudes of respondents, a high level of positive response was documented on WHO recommendations, perceiving the risk of acquiring COVID-19, and the impact of proactive measures on controlling of the pandemic. On the other hand, negative responses were recorded on the adequacy of national preparedness and the capacity of the healthcare system for the fight against COVID-19. A comparable rate of risk perception was reported among nurses in Iran. ${ }^{24}$ Acknowledging the risk of acquiring COVID-19 is essential as it drives individuals to follow safety recommendations. The overall positive attitude rate in this study was $54.1 \%$, which is lower 
Table 3 Predictors of Extent of Knowledge About COVID-19 Among Hospital and Community Pharmacists in Addis Ababa, Ethiopia

\begin{tabular}{|c|c|c|c|c|}
\hline \multirow[t]{2}{*}{ Variables } & \multicolumn{2}{|c|}{ Extent of Knowledge } & \multirow[t]{2}{*}{ COR $(95 \% \mathrm{Cl})$} & \multirow[t]{2}{*}{ AOR $(95 \% \mathrm{Cl})$} \\
\hline & Adequate & Inadequate & & \\
\hline \multicolumn{5}{|l|}{ Age in years } \\
\hline $19-30$ & $83(48.0)$ & $90(52.0)$ & $\mathrm{I}$ & I \\
\hline $31-45$ & $53(57.3)$ & $4 I(42.7)$ & $1.46(0.88,2.40)$ & $0.96(0.53,1.76)$ \\
\hline $46-62$ & $18(69.2)$ & $8(30.8)$ & $2.44(1.01,5.91)$ & $1.09(0.26,4.53)$ \\
\hline \multicolumn{5}{|l|}{ Gender } \\
\hline Female & $69(48.3)$ & 74 (5I.7) & I & I \\
\hline Male & $87(57.2)$ & $65(42.8)$ & $0.70(0.44,1.10)$ & $1.36(0.83,2.24)$ \\
\hline \multicolumn{5}{|l|}{ Professional level } \\
\hline Pharmacy technician & $30(34.5)$ & $57(65.5)$ & 1 & I \\
\hline Pharmacist & $126(60.6)$ & $82(39.4)$ & $2.92(1.73,4.92)$ & $2.65(1.50,4.65)$ \\
\hline \multicolumn{5}{|l|}{ Job Position } \\
\hline Dispenser & $146(53.5)$ & $127(46.5)$ & I & I \\
\hline Store Manager & $10(45.5)$ & $12(54.5)$ & $0.73(0.30,1.73)$ & $0.60(0.24,1.52)$ \\
\hline \multicolumn{5}{|l|}{ Working setup } \\
\hline Community pharmacy & $103(52.6)$ & $93(47.7)$ & I & I \\
\hline Hospital pharmacy & $53(53.5)$ & $46(46.5)$ & $1.04(0.64,1.69)$ & $0.91(0.52,1.58)$ \\
\hline \multicolumn{5}{|l|}{ Year of service } \\
\hline$\leq 5$ & $68(42.5)$ & $92(57.5)$ & I & I \\
\hline $6-15$ & 71 (63.4) & $4 I(36.6)$ & $2.34(1.43,3.85)$ & $2.12(1.18,3.79)$ \\
\hline$\geq 16$ & 17 (73.9) & $6(26.1)$ & $3.83(1.44,10.24)$ & $2.52(0.53,11.99)$ \\
\hline
\end{tabular}

Note: Bold indicates significance $(p<0.05)$.

Abbreviations: $\mathrm{AOR}$, adjusted odds ratio; $\mathrm{Cl}$, confidence interval; $\mathrm{COR}$, crude odds ratio.

Table 4 Attitude Towards COVID-I9 Among Hospital and Community Pharmacists in Addis Ababa, Ethiopia

\begin{tabular}{|c|c|c|c|c|c|c|c|}
\hline Statements & $\begin{array}{l}\text { SA } \\
(\%)\end{array}$ & A (\%) & $\mathbf{N}(\%)$ & $\begin{array}{l}\text { DA } \\
\text { (\%) }\end{array}$ & $\begin{array}{l}\text { SDA } \\
\text { (\%) }\end{array}$ & $\begin{array}{l}\text { Mean } \pm \\
\text { SD }\end{array}$ & $\begin{array}{l}\text { PPR } \\
\text { (\%) }\end{array}$ \\
\hline There is likelihood that I or members of my family acquire COVID-19 & 56.3 & 24.7 & 10.8 & 4.7 & 3.4 & $4.26 \pm 1.05$ & 81 \\
\hline Following WHO recommendations helps to reduce the transmission of COVID-19 & 58.3 & 31.5 & 8.1 & 2.0 & 0.0 & $4.46 \pm 0.73$ & 89.8 \\
\hline $\begin{array}{l}\text { The impact of COVID-19 outbreak can be minimized by the proactive measures } \\
\text { taken by healthcare authorities }\end{array}$ & 25.8 & 29.2 & 25.1 & 11.5 & 8.5 & $3.52 \pm 1.23$ & 55 \\
\hline There is adequate preparedness at national level to deal with COVID-19 outbreak & 14.9 & 20.0 & 38.3 & 15.6 & 11.2 & $3.12 \pm 1.18$ & 34.9 \\
\hline $\begin{array}{l}\text { The healthcare facilities in the country have enough resources to provide care } \\
\text { coronavirus patients }\end{array}$ & 4.4 & 5.4 & 34.6 & 30.5 & 25.1 & $2.34 \pm 1.05$ & 9.8 \\
\hline
\end{tabular}

Abbreviations: A, agree; N, neutral; DA, disagree; SA, strongly agree; SDA, strongly disagree; PPR, percent positive response; SD, standard deviation.

than that of a study by Bhagavathula et al. ${ }^{23}$ The relatively low attitude level in our study can be attributed to the high level of negative response regarding the country's preparedness and capacity to contain potential COVID-19 outbreak.

In this study, the majority of the institutions (community and hospital pharmacies) did not undertake adequate protective measures to protect their employees from COVID-19. They also failed to provide sufficient service related to COVID-19 to the public. The main reason associated with inadequate institutional practice was the scarcity of resources and supplies. Since community pharmacies and hospital pharmacies are integral parts of the fight against COVID-19, problems associated with resources should be resolved quickly to help them provide COVID-19-related services with full capacity. At an individual level, however, a high level of self-protective practice was documented among the study subjects. 
Table 5 Practice Related to COVID-19 Among Hospital and Community Pharmacists in Addis Ababa, Ethiopia

\begin{tabular}{|c|c|}
\hline Variables & $\begin{array}{l}\text { Frequency } \\
\text { (\%) }\end{array}$ \\
\hline $\begin{array}{l}\text { Have adequate protective measures been } \\
\text { taken in your institution to protect the staff } \\
\text { from COVID-19? }(\mathbf{n}=295) \\
\text { Yes } \\
\text { No }\end{array}$ & $\begin{array}{l}88(29.8) \\
207(70.2)\end{array}$ \\
\hline $\begin{array}{l}\text { Reasons for inadequate protection of the staff } \\
\text { from COVID-19 ( } \mathrm{n}-\mathbf{2 0 7 )} \\
\text { Lack of attention/motivation by decision makers } \\
\text { Resource scarcity } \\
\text { Financial constraints } \\
\text { Other reasons }{ }^{\mathrm{a}}\end{array}$ & $\begin{array}{l}81(27.5) \\
177(60.0) \\
71(24.1) \\
14(4.7)\end{array}$ \\
\hline $\begin{array}{l}\text { Is your institution providing adequate service } \\
\text { related to COVID-19? }(\mathbf{n}=\mathbf{2 9 5}) \\
\text { Yes } \\
\text { No }\end{array}$ & $\begin{array}{l}90(30.5) \\
205(69.5)\end{array}$ \\
\hline $\begin{array}{l}\text { Reasons for inadequacy of service related to } \\
\text { COVID-19 }(n=205) \\
\text { Limited supply of equipment or pharmaceuticals } \\
\text { Limited human resource } \\
\text { Inadequate preparedness } \\
\text { Other reasons }{ }^{b}\end{array}$ & $\begin{array}{l}189(64.1) \\
42(14.2) \\
98(33.2) \\
5(1.7)\end{array}$ \\
\hline $\begin{array}{l}\text { Which of the following COVID-19 prevention } \\
\text { measure(s) do you exercise? }(\mathbf{n}=\mathbf{2 9 5}) \\
\text { Washing hands with water and soap } \\
\text { Using personal protective equipment } \\
\text { Avoidance of touching the eyes, nose and mouth } \\
\text { with hands } \\
\text { Maintaining appropriate physical distancing }\end{array}$ & $\begin{array}{l}287(97.3) \\
176(59.7) \\
239(81.0) \\
207(70.2)\end{array}$ \\
\hline
\end{tabular}

Notes: 'O Other reasons - not caring for employees' safety (6), lack of information (3), unsuitable working area (3), downplaying the need (2); ' $\mathrm{C}$ ther reasons - stock out (4) stockpiling of products by competitors (I).

Despite providing valuable information on COVID-19 from the viewpoint of the pharmacy sector, this study has some limitations. The use of a non-probability sampling method may limit the generalizability of the findings of the study. The study tool was prepared by the investigators based on information available on COVID-19 before 15 March 2020 while the global knowledge and practice related to the disease have been changing continually afterward. Therefore, the findings of the study should be interpreted taking these facts into account.

\section{Conclusion}

The study findings confirmed that there is a high level of knowledge on each specific aspect of COVID-19 among the study participants. However, only about half of the participants had adequate knowledge about the disease. The pharmacists showed a predominantly positive attitude towards the importance of WHO recommendations, and predominantly negative attitude towards the country's capacity to deal with the pandemic. The practice related to COVID-19 was inadequate at institutional level. Nevertheless, most of the pharmacists individually exercised self-protective measures against COVID-19. All stakeholders should work on ensuring the adequate supply of materials and services that aid in controlling the pandemic.

\section{Disclosure}

The authors report no conflicts of interest in this work.

\section{References}

1. Zhu N, Zhang D, Wang W, et al. A novel coronavirus from patients with pneumonia in China, 2019. $N$ Engl $J$ Med. 2020;382 (8):727-733. doi:10.1056/NEJMoa2001017

2. Guo Y-R, Cao Q-D, Hong Z-S, et al. The origin, transmission and clinical therapies on coronavirus disease 2019 (COVID-19) outbreak - an update on the status. Mil Med Res. 2020;7(1):11.

3. Jin Y, Yang H, Ji W, et al. Virology, epidemiology, pathogenesis, and control of COVID-19. Viruses. 2020;12(4):372. doi:10.3390/v12040372

4. Sohrabi C, Alsafi Z, O'Neill N, et al. World Health Organization declares global emergency: a review of the 2019 novel coronavirus (COVID-19). Int $J$ Surg. 2020;76:71-76. doi:10.1016/j.ijsu.20 20.02.034

5. Zhou P, Yang X-L, Wang X-G, et al. A pneumonia outbreak associated with a new coronavirus of probable bat origin. Nature. 2020;579(7798):270-273. doi:10.1038/s41586-020-2012-7

6. de Wilde AH, Snijder EJ, Kikkert M, van Hemert MJ. Host factors in coronavirus replication. In: Tripp RA, Tompkins SM, editors. Roles of Host Gene and Non-Coding RNA Expression in Virus Infection. Cham: Springer International Publishing; 2018:1-42.

7. Jiang F, Deng L, Zhang L, Cai Y, Cheung CW, Xia Z. Review of the clinical characteristics of coronavirus disease 2019 (COVID-19). J Gen Intern Med. 2020;35(5):1545-1549. doi:10.1007/s11606-020-05762-w

8. Del Rio C, Malani PN. COVID-19-new insights on a rapidly changing epidemic. JAMA. 2020;323(14):1339. doi:10.1001/jama.2020. 3072

9. Beigel JH, Tomashek KM, Dodd LE, et al. Remdesivir for the treatment of Covid-19 - preliminary report. N Engl J Med. 2020. doi:10.1056/NEJMoa2007764

10. Tian X, Li C, Huang A, et al. Potent binding of 2019 novel coronavirus spike protein by a SARS coronavirus-specific human monoclonal antibody. Emerg Microbes Infect. 2020;9(1):382-385. doi:10. 1080/22221751.2020.1729069

11. Bhattacharya M, Sharma AR, Patra P, et al. Development of epitope-based peptide vaccine against novel coronavirus 2019 (SARS-COV-2): immunoinformatics approach. $J$ Med Virol. 2020;92(6):618-631. doi:10.1002/jmv.25736

12. Wang M, Cao R, Zhang L, et al. Remdesivir and chloroquine effectively inhibit the recently emerged novel coronavirus $(2019-\mathrm{nCoV})$ in vitro. Cell Res. 2020;30(3):269-271. doi:10.1038/s41422-020-0282-0

13. Zeng Y-M, Xu X-L, He X-Q, et al. Comparative effectiveness and safety of ribavirin plus interferon-alpha, lopinavir/ritonavir plus interferon-alpha and ribavirin plus lopinavir/ritonavir plus interferon-alpha in in patients with mild to moderate novel coronavirus pneumonia. Chin Med J 2020;133(9):1132-1134. 
14. Yasri S, Wiwanitkit V. Dose prediction of lopinavir/ritonavir for 2019-novel coronavirus (2019-nCoV) infection based on mathematic modeling. Asian Pac J Trop Med. 2020;13(3):137. doi:10.4103/19957645.277815

15. Coronavirus disease (COVID-19) advice for the public. 2020. Available from: https:/www.who.int/emergencies/diseases/novelcoronavirus-2019/advice-for-public. Accessed April 7, 2020.

16. First Case of COVID-19 Confirmed in ETHIOPIA. 2020. Available from: https://www.afro.who.int/news/first-case-covid-19-confirmedethiopia. Accessed April 24, 2020.

17. Nkengasong JN, Mankoula W. Looming threat of COVID-19 infection in Africa: act collectively, and fast. Lancet. 2020;395 (10227):841-842. doi:10.1016/S0140-6736(20)30464-5

18. Voo T, Capps B. Influenza pandemic and the duties of healthcare professionals. Singapore Med J. 2010;51(4):275-281.

19. Mullen E, Smith GH, Irwin AN, Angeles M. Pandemic H1n1 influenza virus: academy perspectives on pharmacy's critical role in treatment, prevention. J Am Pharm Assoc (2003). 2009;49(6):728. doi:10.1331/JAPhA.2009.09539
20. Cooper J. Preparing for influenza pandemics. Can Pharm J. 2000;133 (3):34.

21. Liu S, Luo P, Tang M, et al. Providing pharmacy services during the coronavirus pandemic. Int J Clin Pharm. 2020;1-6.

22. COVID-19 Preparedness Bulletin Ethiopia. 2020. Available from: https:/extranet.who.int/sph/news/covid-19-preparedness-bulletinethiopia. Accessed April 24, 2020.

23. Bhagavathula AS, Aldhaleei WA, Rahmani J, Mahabadi MA, Bandari DK. Novel coronavirus (COVID-19) knowledge and perceptions: a survey on healthcare workers. medRxiv. 2020.

24. Nemati M, Ebrahimi B, Nemati F. Assessment of Iranian nurses' knowledge and anxiety toward COVID-19 during the current outbreak in Iran. Arch Clin Infect Dis. 2020;15(COVID-19):e102848. doi:10.5812/archcid.102848

25. Giao H, Han NTN, Van Khanh T, Ngan VK, Van Tam V, Le An P. Knowledge and attitude toward COVID-19 among healthcare workers at District 2 hospital, Ho Chi Minh City. Asian Pac J Trop Med. 2020;13(6):260.
Integrated Pharmacy Research and Practice

\section{Publish your work in this journal}

Integrated Pharmacy Research and Practice is an international, peerreviewed, open access, online journal, publishing original research, reports, reviews and commentaries on all areas of academic and professional pharmacy practice. This journal aims to represent the academic output of pharmacists and pharmacy practice with particular focus on integrated care. All papers are carefully peer reviewed
Dovepress

to ensure the highest standards as well as ensuring that we are informing and stimulating pharmaceutical professionals. The manuscript management system is completely online and includes a very quick and fair peer-review system, which is all easy to use. Visit http://www.dovepress.com/testimonials.php to read real quotes from published authors. 